\title{
Quality Evaluation of Flaxseed for Food Use Specifications
}

\author{
Anuradha Vegi ${ }^{1}$, Charlene E. Wolf-Hall ${ }^{2.3}$, \& Clifford A. Hall III ${ }^{1}$ \\ ${ }^{1}$ Department of Plant Sciences, North Dakota State University, North Dakota, USA \\ ${ }^{2}$ Department of Veterinary and Microbiological Sciences, North Dakota State University, North Dakota, USA \\ ${ }^{3}$ Office of the Provost, North Dakota State University, North Dakota, USA \\ Correspondence: Clifford A. Hall III, Department of Plant Sciences, North Dakota State University, Dept. 7670, \\ PO Box 6050, Fargo, North Dakota, 58108-6050, USA. Tel: 1-701-231-6359. E-mail: Clifford.Hall@ndsu.edu
}

$\begin{array}{ll}\text { Received: November 19, } 2016 & \text { Accepted: December 8, } 2016 \quad \text { Online Published: December 18, } 2016 \\ \text { doi:10.5539/jfr.v6n1p59 } & \text { URL: http://dx.doi.org/10.5539/jfr.v6n1p59 }\end{array}$

\begin{abstract}
A Northern Great Plains regional survey of microbiological loads in flaxseed was completed for years 2008 and 2009. Effects of cleaning flaxseed on microbial loads including aerobic plate counts (APCs), mold counts (MCs) yeast counts (YCs), coliform counts (CCs), Escherichia coli counts, and Enterobacteriaceae counts (ECs) were determined. Chemical analyses including oil and linolenic acid -ALA indicated that all flaxseed had near normal oil content. This was the first reported survey for flaxseed. The pre-cleaned flaxseed had an average of $5.7 \pm 0.1$, $4.1 \pm 0.2,4.5 \pm 0.2,3.6 \pm 0.1$, and $3.0 \pm 0.1 \log$ colony forming units $(\mathrm{CFU}) \mathrm{g}^{-1}$ of APC, CC, EC, YC and MC respectively. All counts were higher than those for cleaned seed. No E. coli was detected. The North Dakota-West (ND-W) region flaxseed had higher MC when compared to Canada, ND-North East (ND-NE) and ND-South East (ND-SE) region flaxseed. For APC, the counts were higher in flaxseed from Canada when compared to North Dakota. Cleaning the flaxseed should be considered an important step in reducing the microbial counts and also for maintaining high quality flaxseed.
\end{abstract}

Keywords: flaxseed, microbial loads, coliforms, linolenic acid

\section{Introduction}

Flaxseed (Linum usitatissimum Linnaeus) is a rich source of alpha-linolenic acid (ALA) comprising up to 55\% of the total flaxseed fatty acid content (Chen et al., 1994). Hence, flaxseed's usage as a food ingredient has increased due to the positive results from health studies involving ALA, an omega- 3 fatty acid (Morris \& Vaisey-Genser, 2003). Evidence suggests that ALA consumption can reduce the risk for coronary artery disease, fatal ischemic heart disease among women, and high blood pressure (Berry \& Hirsch, 1986; Hu et al., 1999; Djoussé et al., 2001). Apart from high ALA content, soluble fibre and proteins (22 $\mathrm{g} \mathrm{g}^{-1}$ of seed) are also found in flaxseed (Rubilar et al., 2010). Flaxseed is also a good source for lignans that inhibits some types of diabetes as reported by Mueller et al. (2010). In contrast to the health benefits of flaxseed, quality and safety traits of flaxseed for food-use have not been well defined. Flaxseed is commonly consumed raw, and variable and arbitrary standards exist for raw flaxseed. There is a need to understand what normal microbial loads are for raw flaxseed.

The Federal Grain Inspection Service (FGIS) grades flaxseed into US number 1, US number 2 and US Sample grades, based on test weight, heat damaged kernels, total percent of damaged kernels or a combination thereof. Although these grades are useful to obtain seed of a specific purity, grading of the seed varies from year to year depending on the available crop. The FGIS grading system does not provide information on the microbial counts in flaxseed. Microflora such as bacteria, actinomycetes, molds and yeasts are frequently found on cereal grains (Deible \& Swanson, 2001; Manthey et al., 2004). Viable, but dormant bacteria can occur in large numbers in optimally stored cereal grains with low level of water activity (ICMSF, 1998). Both pathogenic, such as Salmonella spp. and spoilage microflora, such as molds and yeasts, can occur in cereal grains either during preor post- harvest (ICMSF, 1998). Flaxseed and flaxseed based products are susceptible to microbial growth during processing and storage steps where water activities increase.

Microbiological standards for flaxseed and flaxseed products have been deemed necessary by food processors. Current standards used for grain and milled products may not be practical (Manthey et al., 2004; Sperber et al., 2007). This is particularly problematic for flaxseed processors who are expected to meet very stringent market 
specifications for microbial criteria such as coliforms and enterobacteriaceae, which are essentially arbitrary numbers. Also, setting numbers for indicator microbes like coliforms and enterobacteriaceae is not logical as natural, non-fecal, bacteria on raw plant materials will give positive results for these tests (Doyle \& Erickson, 2006). To the best of our knowledge, there is a serious lack of data for establishing scientifically sound criteria for raw flaxseed microbiological quality and safety specifications.

The specific objectives of the study were to evaluate microbial, temporal and chemical aspects of flaxseed and especially, to study the effect of region and year on fatty acid contents of whole flaxseeds for food use. Hence, objectives for the study included collecting flaxseed samples over two-harvest periods for determining temporal, geographic region and cleaning effect on flaxseed microbial loads as well as their physical and chemical characteristics.

\section{Materials and Methods}

\subsection{Sample Collection}

During 2002-2007 crop years, U.S. Census of Agriculture, reported that North Dakota (ND) produced 94-97\% of the nation's flaxseed (NASS, 2009). Hence harvests in North Dakota were targeted for representative flaxseed samples. Flaxseed samples were collected with the help of Northern Crops Institute, Fargo, ND, USA. The pre-cleaned $(\mathrm{n}=54)$ flaxseed samples from two years (2008 and 2009), were collected from 4 different regions (Figure 1; Canada, North Dakota (USA) - north east region (ND-NE), south east region (ND-SE), and west region $(\mathrm{ND}-\mathrm{W})$ ).

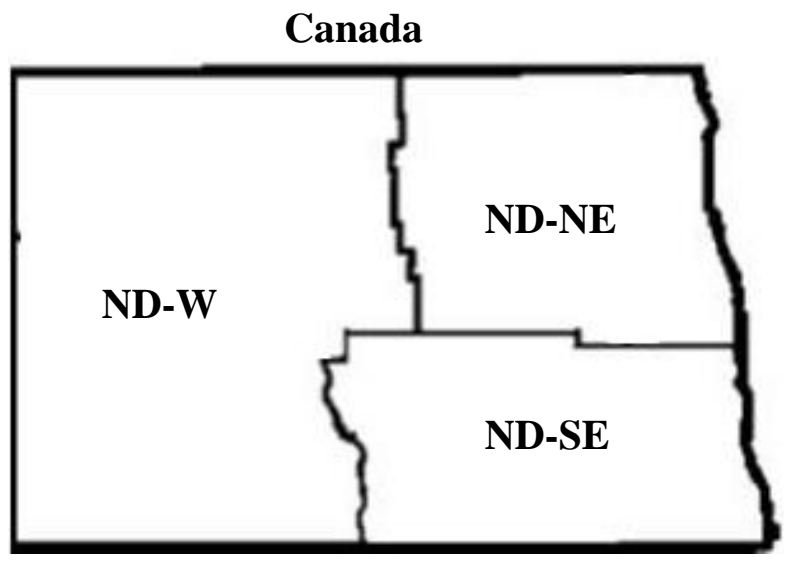

Figure 1. Map of flaxseed collection regions including north east (ND-NE), south east (ND-SE), west (ND-W) regions of North Dakota (USA) and Canada

\subsection{Flaxseed Cleaning}

Flaxseed cleaning was done following the method described by Manthey et al. (2009). A dockage tester (Carter Day International, Minneapolis, MN, USA) was used to remove weed seeds. The dockage tester was configured with a \#25 riddle, \#4 top sieve and \#2 bottom sieve (no middle sieve was used). The air velocity was set at \#3.5. Flaxseed that passed over the \#2 sieve was collected. Flaxseed samples were passed through the tester two times.

\subsection{Microbial Analyses}

Microbial analyses were done on pre-cleaned and cleaned flaxseed to establish microbial loads for populations commonly tested for by the flaxseed industry. These tests included aerobic plate counts (APC), coliform counts (CC), E. coli counts, enterobacteriaceae counts (EC), mold counts (MC) and yeast counts (YC). The tests were done by following methods by Manthey et al. (2004), which included use of Petrifilm products (3M Microbiology, St. Paul, MN, USA).

\subsection{Physical and Chemical Analyses}

The moisture content $(\%)$ and test weight $\left(\mathrm{kg} \mathrm{m}^{-3}\right.$, converted from pounds per bushel to $\left.\mathrm{kg} \mathrm{m}^{-3}\right)$ of the cleaned flaxseed samples were measured using the Grain Analyzer (GAC 2100, DICKEY-John, Auburn, IL, USA) following the standards set by Grain Inspection, Packers and Stockyards Administration (GIPSA, 2004). The cleaned flaxseed samples (50 g) were ground using a Laboratory Falling Number mill (model 3100, Perten Instruments, Springfield, IL, USA). Crude oil content in ground samples (4 g) was determined using a 16-hr 
Soxhlet extraction with hexane following method Ba 3-38 (AOCS, 1998).

Fatty acid composition of the extracted oil was determined by a method described by Lee et al. (2003). The fatty acids were hydrolyzed and determined as methyl esters. Analysis was done on a HP5890 gas chromatograph (Hewlett Packard, Palo Alto, CA, USA) which was fitted with a flame-ionization detector and equipped with a SP2330 fused silica capillary column $(30 \mathrm{~m} \times 0.25 \mathrm{~mm}$, i.d., and $0.20 \mu \mathrm{m}$ film thickness) (Supelco, Bellefonte, CA, USA). The chromatography conditions for $1 \mu \mathrm{L}$ of sample injected were: column flow rate $1 \mathrm{~mL} \mathrm{~min}^{-1}$, initial column temperature $150{ }^{\circ} \mathrm{C}$ (held for $5 \mathrm{~min}$ ), raised $10{ }^{\circ} \mathrm{C} \mathrm{min}^{-1}$ to a final temperature of $180{ }^{\circ} \mathrm{C}$, and injector and detector temperatures were held at $200{ }^{\circ} \mathrm{C}$. Individual fatty acids (palmitic acid (PA), stearic acid (SA), oleic acid (OA), linoleic acid (LA), and linolenic acid (ALA)) were confirmed by retention times and quantified against peak area standard plots of known fatty acid concentrations.

\subsection{Experimental Design and Statistics}

The microbial count data were evaluated for the effect of year, region and type (clean or pre-clean). The effect of region and year was evaluated on physical and chemical characteristics including fatty acid contents of the cleaned flaxseed samples. Analyses of maximum likelihood parameter estimates were performed using the procedure for generalized linear model (PROC GENMOD) of statistical software SAS (Version 9.2; SAS Institute, Inc., Cary, NC, USA) for microbial counts. Analyses of least square estimates were performed using another procedure for general linear model (PROC GLM) of SAS to analyze the physical and chemical data. All statements of statistical significance are based on $P<0 \cdot 05$.

\section{Results and Discussion}

\subsection{Microbial Analyses}

The temporal effect was evaluated on the microbial counts including APC, CC, EC, MC and YC (Table 1). The effect of geographical region, and type (pre-clean or clean) of flaxseed on microbial counts was also evaluated (Tables 2 and 3). The geographic region where the flaxseed was grown, year and type of flaxseed had a significant $(\mathrm{P}<0.05)$ effect on the flaxseed APC and EC values. The pre-cleaned flaxseed APC ranged between 2.1 to $7.1 \log$ CFU g ${ }^{-1}$ (Table 2) for 2008 and 2009 crops, and resulted in an average APC of approximately $5.7 \pm$ $0.1 \log \mathrm{CFU} \mathrm{g}{ }^{-1}$. Similarly, the average EC values in pre-cleaned flaxseed were $4.5 \pm 0.2 \log \mathrm{CFU} \mathrm{g}{ }^{-1}$, and ranged between 0 to $6.4 \log$ CFU g ${ }^{-1}$ (Table 2). The APC and EC were significantly $(\mathrm{P}<0.05)$ lower in year 2009 when compared to 2008 (Table 1). Also, the APC were significantly $(\mathrm{P}<0.05)$ higher in Canadian samples, when compared to the North Dakota region samples. The ND-NE, ND-SE and ND-W pre-cleaned flaxseed samples were not significantly different in the mean APC values (Table 2). The mean EC were not significantly different among the pre-cleaned flaxseed obtained from different regions. Cleaning the flaxseed significantly reduced (P $<0.05) \mathrm{APC}$ and EC values. For cleaned flaxseed, the average APC were $5.0 \pm 0.1 \log \mathrm{CFU} \mathrm{g}{ }^{-1}$ whereas the average EC were $3.7 \pm 0.2 \log \mathrm{CFU} \mathrm{g}{ }^{-1}$ (Table 3). Similar results were observed by Manthey et al. (2004), where cleaning dirty wheat, on average, resulted in approximately a $1-\log$ reduction in CFU $\mathrm{g}^{-1}$ for APCs. The pre-cleaned flaxseed contained foreign materials such as shaft and weed seeds, which may have contributed to higher microbial counts.

Table 1. Effect of time on chemical, microbial and physical profile of flaxseed

\begin{tabular}{lll}
\hline & \multicolumn{2}{c}{ Mean Value } \\
\cline { 2 - 3 } & Year 2008 & Year 2009 \\
\hline Aerobic Plate Count $\left(\log \mathrm{CFU} \mathrm{g}^{-1}\right)$ & $5.5^{\mathrm{A}}$ & $5.1^{\mathrm{B}}$ \\
Coliform Count $\left(\log \mathrm{CFU} \mathrm{g} \mathrm{g}^{-1}\right)$ & $3.7^{\mathrm{A}}$ & $3.8^{\mathrm{A}}$ \\
Enterobacteriaceae Count $\left(\log \mathrm{CFU} \mathrm{g}^{-1}\right)$ & $4.3^{\mathrm{A}}$ & $3.8^{\mathrm{B}}$ \\
Mold Count $\left(\log \mathrm{CFU} \mathrm{g} \mathrm{g}^{-1}\right)$ & $2.7^{\mathrm{A}}$ & $2.6^{\mathrm{A}}$ \\
Yeast Count $\left(\log \mathrm{CFU} \mathrm{g} \mathrm{g}^{-1}\right)$ & $3.2^{\mathrm{A}}$ & $3.3^{\mathrm{A}}$ \\
Test Weight $\left(\mathrm{kg} \mathrm{m}^{-3}\right)$ & $629.3^{\mathrm{A}}$ & $595.9^{\mathrm{B}}$ \\
Moisture $(\%)$ & $7.7^{\mathrm{A}}$ & $6.5^{\mathrm{B}}$ \\
Oil (\%) & $41.6^{\mathrm{A}}$ & $42.4^{\mathrm{A}}$ \\
Palmitic Acid (\%) & $5.6^{\mathrm{A}}$ & $4.7^{\mathrm{B}}$ \\
Stearic Acid (\%) & $2.3^{\mathrm{B}}$ & $3.4^{\mathrm{A}}$ \\
Oleic Acid (\%) & $21.1^{\mathrm{A}}$ & $19.4^{\mathrm{A}}$ \\
Linoleic Acid (\%) & $15.8^{\mathrm{B}}$ & $16.8^{\mathrm{A}}$ \\
Linolenic Acid (\%) & $55.3^{\mathrm{A}}$ & $55.6^{\mathrm{A}}$ \\
\hline in superscript within the same row indicates mean values are significantly different at $\alpha=0.05$
\end{tabular}

Different capitalized letters in superscript within the same row indicates mean values are significantly different at $\alpha=0.05$ 
Table 2. Microbial counts for pre-cleaned flaxseed obtained from various regions (2008 - 2009)

\begin{tabular}{|c|c|c|c|c|c|}
\hline $\mathrm{N}$ & Region & $\begin{array}{l}\text { Mean APC } \pm \text { SE } \\
\left(\log C F U g^{-1}\right)\end{array}$ & $\begin{array}{l}\text { Range for APC } \\
\left(\log \mathrm{CFU} \mathrm{g}^{-1}\right)\end{array}$ & $\begin{array}{l}\text { Median for APC } \\
\left(\log C F U g^{-1}\right)\end{array}$ & $\begin{array}{l}\text { Mode for APC } \\
\left(\log C F \mathrm{~g}^{-1}\right)\end{array}$ \\
\hline 9 & Canada & $6.3 \pm 0.2^{\mathrm{A}}$ & $5.5-7.1$ & 6.2 & None \\
\hline 8 & ND-NE & $5.5 \pm 0.1^{\mathrm{B}}$ & $4.9-5.9$ & 5.5 & 5.5 \\
\hline 11 & ND-SE & $5.5 \pm 0.2^{\mathrm{B}}$ & $3.8-6.2$ & 5.8 & None \\
\hline \multirow[t]{2}{*}{26} & $\mathrm{ND}-\mathrm{W}$ & $5.5 \pm 0.2^{\mathrm{B}}$ & $2.1-6.3$ & 5.8 & 5.7 \\
\hline & Average \& Range & $5.7 \pm 0.1$ & $2.1-7.1$ & 5.8 & 5.5 \\
\hline $\mathrm{N}$ & Region & $\begin{array}{l}\text { Mean CC } \pm \text { SE } \\
\left(\log C F U g^{-1}\right)\end{array}$ & $\begin{array}{l}\text { Range for CC } \\
\left(\log C F U g^{-1}\right)\end{array}$ & $\begin{array}{l}\text { Median for CC } \\
\left(\log C F U g^{-1}\right)\end{array}$ & $\begin{array}{l}\text { Mode for CC } \\
\left(\log C F U g^{-1}\right)\end{array}$ \\
\hline 9 & Canada & $4.6 \pm 0.4^{\mathrm{A}}$ & $2.3-6.0$ & 4.7 & None \\
\hline 8 & ND-NE & $4.4 \pm 0.2^{\mathrm{A}}$ & $3.6-5.3$ & 4.5 & None \\
\hline 11 & ND-SE & $4.0 \pm 0.4^{\mathrm{A}}$ & $2.2-6.0$ & 4.2 & None \\
\hline \multirow[t]{2}{*}{26} & ND-W & $3.8 \pm 0.3^{\mathrm{A}}$ & $0.0-5.8$ & 4.3 & 1.2 \\
\hline & Average \& Range & $4.1 \pm 0.2$ & $0.0-6.0$ & 4.5 & 4.6 \\
\hline $\mathrm{N}$ & Region & $\begin{array}{l}\text { Mean EC } \pm \text { SE } \\
\left(\log C F U g^{-1}\right)\end{array}$ & $\begin{array}{l}\text { Range for EC } \\
\left(\log C F U g^{-1}\right)\end{array}$ & $\begin{array}{l}\text { Median for EC } \\
\left({\left.\log C F U ~ ~^{-1}\right)}^{-1}\right.\end{array}$ & $\begin{array}{l}\text { Mode for EC } \\
\left(\log C F U g^{-1}\right)\end{array}$ \\
\hline 9 & Canada & $5.4 \pm 0.3^{\mathrm{A}}$ & $3.0-6.4$ & 5.9 & None \\
\hline 8 & ND-NE & $4.7 \pm 0.2^{\mathrm{A}}$ & $3.8-5.3$ & 4.8 & None \\
\hline 11 & ND-SE & $4.4 \pm 0.4^{\mathrm{A}}$ & $2.2-5.7$ & 4.9 & 5.2 \\
\hline \multirow[t]{2}{*}{26} & ND-W & $4.2 \pm 0.3^{\mathrm{A}}$ & $0.0-6.3$ & 4.8 & 1.2 \\
\hline & Average \& Range & $4.5 \pm 0.2$ & $0.0-6.4$ & 5.0 & 5.3 \\
\hline $\mathrm{N}$ & Region & $\begin{array}{l}\text { Mean YC } \pm \text { SE }(\log \\
\text { CFU g }\end{array}$ & $\begin{array}{l}\text { Range for YC } \\
\left(\log C F U g^{-1}\right)\end{array}$ & $\begin{array}{l}\text { Median for YC } \\
\left(\log C F \mathrm{~g}^{-1}\right)\end{array}$ & $\begin{array}{l}\text { Mode for YC } \\
\left(\log C F U g^{-1}\right)\end{array}$ \\
\hline 9 & Canada & $3.3 \pm 0.2^{\mathrm{A}}$ & $2.6-4.3$ & 3.3 & None \\
\hline 8 & ND-NE & $3.3 \pm 0.1^{\mathrm{A}}$ & $2.9-3.6$ & 3.4 & None \\
\hline 11 & ND-SE & $3.3 \pm 0.2^{\mathrm{A}}$ & $2.2-4.2$ & 3.6 & None \\
\hline \multirow[t]{2}{*}{26} & ND-W & $3.8 \pm 0.1^{\mathrm{A}}$ & $2.7-5.2$ & 3.7 & 3.5 \\
\hline & Average \& Range & $3.6 \pm 0.1$ & $2.7-5.2$ & 3.6 & 3.6 \\
\hline $\mathrm{N}$ & Region & $\begin{array}{l}\text { Mean MC } \pm \text { SE }(\log \\
\text { CFU g } \\
-1)\end{array}$ & $\begin{array}{r}\text { Range for MC } \\
\left(\log C F U g^{-1}\right)\end{array}$ & $\begin{array}{l}\text { Median for MC } \\
\left(\log C F \mathrm{~g}^{-1}\right)\end{array}$ & $\begin{array}{l}\text { Mode for MC } \\
\left(\log C F U g^{-1}\right)\end{array}$ \\
\hline 9 & Canada & $2.7 \pm 0.2^{\mathrm{B}}$ & $2.1-3.5$ & 2.6 & None \\
\hline 8 & ND-NE & $2.7 \pm 0.1^{\mathrm{B}}$ & $2.1-3.1$ & 2.8 & 2.9 \\
\hline 11 & ND-SE & $2.6 \pm 0.2^{\mathrm{B}}$ & $1.3-3.5$ & 2.8 & None \\
\hline \multirow[t]{2}{*}{26} & ND-W & $3.5 \pm 0.2^{\mathrm{A}}$ & $1.3-5.9$ & 3.3 & None \\
\hline & Average \& Range & $3.0 \pm 0.1$ & $1.3-5.9$ & 3.0 & 2.9 \\
\hline
\end{tabular}

Note: ND-NE indicates North Dakota (US) - North East region; ND-SE indicates North Dakota (US) - South East region; ND-W indicates North Dakota - West region; SE indicates Standard Error; APC indicates Aerobic Plate Count; CC indicates Coliform Count; EC indicates Enterobacteriaceae Count; YC indicates Yeast Count; MC indicates Mold Count; Different capitalized letters in superscript within the same column indicates mean values are significantly different at $\alpha=0.05$

The average CC values of $4.1 \pm 0.2 \log \mathrm{CFU} \mathrm{g}{ }^{-1}$ and $3.4 \pm 0.2 \log \mathrm{CFU} \mathrm{g}{ }^{-1}$ were observed, respectively in the pre-cleaned and cleaned flaxseed samples from 2008 and 2009 (Tables 2 and 3). Similar to the average EC values, there were no significant differences in average $\mathrm{CC}$ values among the four flaxseed production regions for both pre-cleaned and cleaned samples (Tables 2-3). Also, no significant differences in CC values were observed between 2008 and 2009 flaxseed samples (Table 1). Regardless of the microorganisms tested, the pre-cleaned flaxseed had significantly $(\mathrm{P}<0.05)$ higher microbial numbers. No E. coli were detected in the samples in either 2008 or 2009 . The E. coli assay is a more reliable indicator of fecal contamination, and could serve as an alternative to the fecal coliform assay (Doyle \& Erickson, 2006). This reasoning also applies to the EC test.

The average YC and MC for pre-cleaned flaxseed from 2008 and 2009 crop years were $3.6 \pm 0.1 \log$ CFU g ${ }^{-1}$ and $3.0 \pm 0.1 \log \mathrm{CFU} \mathrm{g}{ }^{-1}$, respectively (Table 2$)$. The yeast counts were significantly $(\mathrm{P}<0.05)$ lower with a mean value of $3.0 \pm 0.1 \log \mathrm{CFU} \mathrm{g}{ }^{-1}$, and the mold counts significantly (P<0.05) reduced to $2.3 \pm 0.1 \log \mathrm{CFU}$ $\mathrm{g}^{-1}$ in cleaned flaxseed (Table 3). The 2009 flaxseed yeast and mold counts also were not significantly $(\mathrm{P}>0.05)$ different when compared year 2008 (Table 1). Also, when compared to ND-W region MC in pre-cleaned 
flaxseed were significantly $(\mathrm{P}<0.05)$ lower in samples of Canada, ND-NE and ND-SE regions; however, no such difference was observed among different regions for average $\mathrm{YC}$ counts in pre-cleaned flaxseed (Table 2). In cleaned flaxseed, the average YC were higher in ND-SE and ND-W region samples were significantly $(\mathrm{P}<0.05)$ higher when compared to Canada and ND-NE samples. The MC, however, had higher average values in cleaned flaxseed from Canada and ND-W when compared to ND-NE and ND-SE region samples (Table 3).

Table 3. Microbial counts for cleaned flaxseed obtained from various regions $(2008-2009)$

\begin{tabular}{|c|c|c|c|c|c|}
\hline $\mathrm{N}$ & Region & $\begin{array}{c}\text { Mean APC } \pm \text { SE }(\log \\
\text { CFU g g } \\
\end{array}$ & $\begin{array}{l}\text { Range for APC } \\
\left.(\log \text { CFU g })^{-1}\right)\end{array}$ & $\begin{array}{l}\text { Median for APC } \\
\left.(\log \text { CFU g })^{-1}\right)\end{array}$ & $\begin{array}{c}\text { Mode for APC } \\
\left(\log \text { CFU g }{ }^{-1}\right)\end{array}$ \\
\hline 9 & Canada & $6.1 \pm 0.2^{\mathrm{A}}$ & $5.4-7.0$ & 6.0 & None \\
\hline 8 & ND-NE & $4.8 \pm 0.3^{\mathrm{B}}$ & $3.8-5.6$ & 4.9 & 5.6 \\
\hline 11 & ND-SE & $5.1 \pm 0.3^{\mathrm{B}}$ & $2.7-6.0$ & 4.8 & None \\
\hline \multirow[t]{2}{*}{26} & ND-W & $4.6 \pm 0.2^{\mathrm{B}}$ & $2.3-5.9$ & 4.8 & None \\
\hline & Average \& Range & $5.0 \pm 0.1$ & $2.3-7.0$ & 5.0 & 5.6 \\
\hline $\mathrm{N}$ & Region & $\begin{array}{c}\text { Mean CC } \pm \text { SE } \\
\left(\log C F U g^{-1}\right)\end{array}$ & $\begin{array}{l}\text { Range for CC } \\
\left(\log C F U g^{-1}\right)\end{array}$ & $\begin{array}{l}\text { Median for CC } \\
\left(\log C F U g^{-1}\right)\end{array}$ & $\begin{array}{l}\text { Mode for CC } \\
\left(\log C F U g^{-1}\right)\end{array}$ \\
\hline 9 & Canada & $3.6 \pm 0.4^{\mathrm{A}}$ & $1.8-5.7$ & 3.4 & None \\
\hline 8 & ND-NE & $3.5 \pm 0.3^{\mathrm{A}}$ & $2.6-4.9$ & 3.2 & None \\
\hline 11 & ND-SE & $3.6 \pm 0.4^{\mathrm{A}}$ & $1.7-4.6$ & 4.3 & None \\
\hline \multirow[t]{2}{*}{26} & ND-W & $3.2 \pm 0.3^{\mathrm{A}}$ & $0.0-5.8$ & 3.6 & 0.0 \\
\hline & Average \& Range & $3.4 \pm 0.2$ & $0.0-5.8$ & 3.4 & 0.0 \\
\hline $\mathrm{N}$ & Region & $\begin{array}{c}\text { Mean EC } \pm \text { SE } \\
\left(\log C F U g^{-1}\right)\end{array}$ & $\begin{array}{l}\text { Range for EC } \\
\left(\log C F U g^{-1}\right)\end{array}$ & $\begin{array}{l}\text { Median for EC } \\
\left(\log C F U g^{-1}\right)\end{array}$ & $\begin{array}{l}\text { Mode for EC } \\
\left(\log C F U ~^{-1}\right)\end{array}$ \\
\hline 9 & Canada & $4.2 \pm 0.5^{\mathrm{A}}$ & $2.0-5.6$ & 5.2 & 5.2 \\
\hline 8 & ND-NE & $3.8 \pm 0.2^{\mathrm{A}}$ & $2.9-5.0$ & 3.5 & None \\
\hline 11 & ND-SE & $4.4 \pm 0.3^{\mathrm{A}}$ & $1.9-4.3$ & 4.6 & 5.2 \\
\hline \multirow[t]{3}{*}{26} & ND-W & $3.2 \pm 0.3^{\mathrm{A}}$ & $0.0-5.6$ & 3.2 & 1.2 \\
\hline & Average \& Range & $3.7 \pm 0.2$ & $0.0-5.6$ & 3.8 & 5.2 \\
\hline & Region & $\begin{array}{c}\text { Mean } \mathrm{YC} \pm \mathrm{SE}(\log \\
\left.\mathrm{CFU} \mathrm{g} \mathrm{g}^{-1}\right)\end{array}$ & $\begin{array}{l}\text { Range for YC } \\
\left(\log C F U g^{-1}\right)\end{array}$ & $\begin{array}{l}\text { Median for YC } \\
\left(\log C F U g^{-1}\right)\end{array}$ & $\begin{array}{l}\text { Mode for YC } \\
\left(\log C F U g^{-1}\right)\end{array}$ \\
\hline 9 & Canada & $2.8 \pm 0.1^{\mathrm{BA}}$ & $2.3-3.4$ & 2.7 & None \\
\hline 8 & ND-NE & $2.4 \pm 0.1^{\mathrm{B}}$ & $2.1-3.1$ & 2.4 & None \\
\hline 11 & ND-SE & $3.2 \pm 0.2^{\mathrm{A}}$ & $2.5-3.8$ & 3.0 & None \\
\hline \multirow[t]{3}{*}{26} & ND-W & $3.1 \pm 0.1^{\mathrm{A}}$ & $1.5-4.4$ & 3.1 & 2.5 \\
\hline & Average \& Range & $3.0 \pm 0.1$ & $1.5-4.4$ & 2.9 & 2.5 \\
\hline & Region & $\begin{array}{c}\text { Mean } \mathrm{MC} \pm \mathrm{SE}(\log \\
\left.\mathrm{CFU} \mathrm{\textrm {g } ^ { - 1 }}\right)\end{array}$ & $\begin{array}{l}\text { Range for MC } \\
\left(\log C F U g^{-1}\right)\end{array}$ & $\begin{array}{l}\text { Median for MC } \\
\left(\log C F U g^{-1}\right)\end{array}$ & $\begin{array}{l}\text { Mode for MC } \\
\left(\log C F \mathrm{~g}^{-1}\right)\end{array}$ \\
\hline 9 & Canada & $2.4 \pm 0.1^{\mathrm{A}}$ & $1.9-3.2$ & 2.4 & 2.7 \\
\hline 8 & ND-NE & $1.7 \pm 0.1^{\mathrm{B}}$ & $1.3-2.0$ & 1.7 & 1.3 \\
\hline 11 & ND-SE & $2.2 \pm 0.1^{\mathrm{BA}}$ & $1.6-2.9$ & 2.3 & None \\
\hline \multirow[t]{2}{*}{26} & ND-W & $2.6 \pm 0.2^{\mathrm{A}}$ & $0.0-4.6$ & 2.7 & 3.0 \\
\hline & Average \& Range & $2.3 \pm 0.1$ & $0.0-4.6$ & 2.3 & 2.7 \\
\hline
\end{tabular}

Note: ND-NE indicates North Dakota (US) - North East region; ND-SE indicates North Dakota (US) - South East region; ND-W indicates North Dakota - West region; SE indicates Standard Error; APC indicates Aerobic Plate Count; CC indicates Coliform Count; EC indicates Enterobacteriaceae Count; YC indicates Yeast Count; MC indicates Mold Count; Different capitalized letters in superscript within the same column indicates mean values are significantly different at $\alpha=0.05$

The cleaned flaxseed microbial data falls in the range reported for cereal grains. Most of the flaxseed samples had APC in the range of $10^{2}-10^{5}(100-100,000)$ CFU g ${ }^{-1}$. Only a few samples had APC in the $10^{6}-10^{7}$ (i.e. 1 -10 million) $\mathrm{CFU} \mathrm{g}{ }^{-1}$ range. The APC between $10^{2}$ and $10^{6} \mathrm{CFU} \mathrm{g}^{-1}$ are common for cereal grains. Graves et al. (1967), reported that in Kansas-Nebraska and Pacific Northwest regions, the wheat had total bacterial counts in the range of $15,000-660,000 \mathrm{~g}^{-1}\left(4.2-5.8 \log \mathrm{CFU} \mathrm{g}{ }^{-1}\right)$ in wheat. In more modern times, and in clean wheat, the average APC was reported to be $7.2 \pm 0.5 \log \mathrm{CFU} \mathrm{g}^{-1}, 7$, whereas for brown rice, it was around an average of $7.2 \pm 0.3 \log \mathrm{CFU} \mathrm{g}^{-1}$ (Skyrme et al. 1998). Yeast and mold counts are typically in the $10^{2}$ and $10^{4} \mathrm{CFU} \mathrm{g}^{-1} \mathrm{range}^{3}$ for cereal grains. Cleaned flaxseed had yeast and mold counts that were $10^{3} \mathrm{CFU} \mathrm{g} \mathrm{g}^{-1}$ or lower levels. They were similar to the values for wheat reported by Manthey et al. (2004), where the average mold and yeast counts were 
$3.5 \pm 0.8 \log \mathrm{CFU} \mathrm{g}{ }^{-1}$. After cleaning, the $\mathrm{CC}$ ranged from none to $6.0 \log \mathrm{CFU} \mathrm{g}^{-1}$ in flaxseed, whereas for the brown rice the CC were around $2.4 \pm 0.6 \log \mathrm{CFU} \mathrm{g}{ }^{-1}$ according to Skyrme et al. (1998). Furthermore, some flax producing regions did have higher counts than others (Tables 2 and 3).

\subsection{Chemical and Physical Analyses}

The average test weight was $615.2 \pm 6.4 \mathrm{~kg} \mathrm{~m}^{-3}$ for the flaxseed obtained from 2008 and 2009 crop years (Table 4). The test weight for the flaxseed from the 2008 crop year averaged significantly higher $(\mathrm{P}<0.05)$ than in year 2009 (Table 1). As a result, the flaxseed obtained from some regions fell below the U.S. No. 2 grade while other samples met the grade No. 1. It should be noted that the additional cleaning may improve the lower test weight samples into the number 2 grade. Of the different regions involved, test weight of the flaxseed obtained from ND-NE and ND-SE were significantly $(\mathrm{P}<0.05)$ higher than in Canada and ND-W regions. A similar physical measurement of flaxseed, bulk density, was reported to be in the range of 556-727 $\mathrm{kg} \mathrm{m}^{-3}$ when the moisture levels of the flaxseed was in the range of 6.1-16.8\% (Coskuner \& Karababa, 2007).

Table 4. Physical and chemical characteristics of the flaxseed obtained from various regions $(2008-2009)$

\begin{tabular}{cccccc}
\hline $\mathrm{N}$ & Region & $\begin{array}{c}\text { Mean Test Weight } \\
\pm \mathrm{SE}\left(\mathrm{kg} \mathrm{m}^{-3}\right)\end{array}$ & $\begin{array}{c}\text { Range for Test } \\
\text { Weight }\left(\mathrm{kg} \mathrm{m}^{-3}\right)\end{array}$ & $\begin{array}{c}\text { Median for Test } \\
\text { Weight }\left(\mathrm{kg} \mathrm{m}^{-3}\right)\end{array}$ & $\begin{array}{c}\text { Mode for Test } \\
\text { Weight }\left(\mathrm{kg} \mathrm{m}^{-3}\right)\end{array}$ \\
\hline 9 & Canada & $611.3 \pm 6.4^{\mathrm{B}}$ & $574.0-635.8$ & 616.5 & None \\
8 & ND-NE & $646.1 \pm 7.7^{\mathrm{A}}$ & $597.2-657.7$ & 655.1 & 655.1 \\
11 & ND-SE & $649.9 \pm 2.6^{\mathrm{A}}$ & $631.9-667.9$ & 648.6 & 648.6 \\
26 & ND-W & $593.3 \pm 9.0^{\mathrm{B}}$ & $491.6-661.5$ & 604.9 & 625.5 \\
& Average \& Range & $615.2 \pm 6.4$ & $491.6-667.9$ & 626.8 & 648.6 \\
\hline & & Mean Moisture & Range for & Median for & Mode for \\
$\mathrm{N}$ & Region & $\pm \mathrm{SE}(\%)$ & Moisture $(\%)$ & Moisture (\%) & Moisture $(\%)$ \\
\hline 9 & Canada & $8.6 \pm 0.1^{\mathrm{A}}$ & $8.0-9.2$ & 8.6 & 8.3 \\
8 & ND-NE & $7.1 \pm 0.1^{\mathrm{B}}$ & $6.5-7.5$ & 7.2 & 7.2 \\
11 & ND-SE & $6.5 \pm 0.2^{\mathrm{B}}$ & $6.0-8.0$ & 6.3 & 6.3 \\
26 & ND-W & $7.0 \pm 0.3^{\mathrm{B}}$ & $5.8-12.5$ & 6.5 & 6.3 \\
& Average \& Range & $7.2 \pm 0.2$ & $5.8-12.5$ & 6.8 & 6.3 \\
$\mathrm{~N}$ & & Mean Oil $\pm \mathrm{SE}$ & Range for Oil & Median for Oil & Mode for Oil \\
\hline 9 & Region & $(\%)$ & $(\%)$ & $(\%)$ & $(\%)$ \\
8 & Canada & $43.7 \pm 0.6^{\mathrm{A}}$ & $40.5-46.3$ & 43.6 & 43.6 \\
11 & ND-NE & $42.0 \pm 0.7^{\mathrm{A}}$ & $39.4-44.4$ & 42.4 & 42.5 \\
26 & ND-SE & $40.1 \pm 0.8^{\mathrm{B}}$ & $36.1-43.5$ & 40.2 & 37.2 \\
& ND-W & $42.1 \pm 0.4^{\mathrm{A}}$ & $38.0-46.5$ & 42.2 & None \\
\hline
\end{tabular}

Note: ND-NE indicates North Dakota (US) - North East region; ND-SE indicates North Dakota (US) - South East region; ND-W indicates North Dakota - West region; SE indicates Standard Error; Different capitalized letters in superscript within the same column indicates mean values are significantly different at $\alpha=0.05$

Variability in the moisture content was also observed. The highest moisture content was observed in seeds from the 2008 harvest year than in year 2009. The overall flaxseed averaged $7.2 \pm 0.2 \%$ moisture, with the highest moisture $(8.6 \pm 0.1 \%)$ observed in flaxseed from Canada (Table 4). The Canadian samples had significantly higher $(\mathrm{P}<0.05)$ moisture when compared to ND-NE, ND-SE and ND-W regions. The production region did not appear to be the determining factor regarding moisture content as flaxseed obtained from ND regions, which were not significantly different from each other except for Canadian samples. Thus, the growth year and level of precipitation at harvest may have resulted in moisture contents being higher in 2008. However, the average moisture content between these two years was 7.2\%. Generally, increased moisture contents of flaxseed have been reported to affect some of the physical properties of flaxseed, and in turn may also affect the processing, transport and storage of the flaxseed. Certain physical characteristics such as, one thousand seed weight, bulk density, true density and their relationship to flaxseed moisture content was studied (Coskuner \& Karababa, 2007). In that study, when the moisture of flaxseed increased from 6.1 to $16.8 \%$, a linear increase in both one thousand seed weight ( 4.8 to $5.3 \mathrm{~g}$ ) and true density $\left(1000\right.$ to $\left.1111 \mathrm{~kg} \mathrm{~m}^{-3}\right)$ was observed; whereas there was a decrease in bulk density from 727 to 556 (Coskuner \& Karababa, 2007).

The average oil content of flaxseed from 2009 was not significantly different than the average oil content from the 2008 crop (Table 1). The overall flaxseed oil content ranged from 36.1 to $46.5 \%$ and averaged at $41.9 \pm 0.3 \%$ 
(Table 4). The oil contents of the samples are typical of those obtained from previous years typically analyzed in our laboratory. Historical data observed on North Dakota grown flaxseed indicates an oil level of 32-38\% (Hettiarachchy et al. 1990). Higher oil content reported in the current study also indicates higher nutritive value of the seed grown in cooler climates. The only significantly $(\mathrm{P}<0.05)$ lower oil contents were seen in ND-SE region and rest of the regions were not statistically different in oil content (Table 4). Also, the soxhlet with hexane extracted oil from flaxseed in the current study (range of 36.1 to $46.5 \%$ ) was very similar in values (45.2\% of oil) that were reported by Mueller et al. 2010. Cultivars of the flaxseed were unknown and not analyzed.

The fatty acids (PA, SA, OA and LA) in the flaxseed oil varied among various regions that were tested (Table 5). On average, PA, SA, OA and LA for the flaxseed in the present study were 5.2\%, 2.8\%, 20.4\% and $16.2 \%$ respectively. The results were similar to those reported earlier by Bean \& Leeson (2002), who observed that the flaxseed had 5.6\%, 3.2\%, $18.5 \%$ and $14.4 \%$ respectively of PA, SA, OA and LA. In the present study, Canadian samples had significantly $(\mathrm{P}<0.05)$ lower average values of SA $(1.7 \%)$ and LA $(15.2 \%)$ when compared to ND regions. ND-SE region had significantly $(\mathrm{P}<0.05)$ higher average OA $(23.8 \%)$ when compared to other regions; whereas ND-NE had significantly $(\mathrm{P}<0.05)$ higher PA $(6.2 \%)$ (Table 5).

Table 5. Fatty acid profile of the flaxseed obtained from various regions $(2008-2009)$

\begin{tabular}{|c|c|c|c|c|c|}
\hline $\mathrm{N}$ & Region & $\begin{array}{c}\text { Mean PA } \pm \text { SE } \\
(\% \text { Oil })\end{array}$ & $\begin{array}{l}\text { Range for PA } \\
(\% \text { Oil })\end{array}$ & $\begin{array}{l}\text { Median for PA } \\
(\% \text { Oil })\end{array}$ & $\begin{array}{l}\text { Mode for PA } \\
(\% \text { Oil })\end{array}$ \\
\hline 9 & Canada & $5.4 \pm 0.3^{\mathrm{BA}}$ & $4.5-6.8$ & 5.2 & 4.9 \\
\hline 8 & ND-NE & $6.2 \pm 0.5^{\mathrm{A}}$ & $4.9-9.6$ & 6.0 & None \\
\hline 11 & ND-SE & $5.0 \pm 0.3^{\mathrm{B}}$ & $2.9-6.0$ & 5.0 & 5.2 \\
\hline \multirow[t]{2}{*}{26} & ND-W & $5.0 \pm 0.2^{\mathrm{B}}$ & $3.2-7.8$ & 4.8 & 4.6 \\
\hline & Average \& Range & $5.2 \pm 0.1$ & $2.9-9.6$ & 5.0 & 5.2 \\
\hline $\mathrm{N}$ & Region & $\begin{array}{c}\text { Mean SA } \pm \text { SE } \\
(\% \text { Oil })\end{array}$ & $\begin{array}{l}\text { Range for SA } \\
\quad(\% \text { Oil })\end{array}$ & $\begin{array}{l}\text { Median for SA } \\
(\% \text { Oil })\end{array}$ & $\begin{array}{l}\text { Mode for SA } \\
\quad(\% \text { Oil })\end{array}$ \\
\hline 9 & Canada & $1.7 \pm 0.3^{\mathrm{B}}$ & $0.6-3.1$ & 1.5 & 1.5 \\
\hline 8 & ND-NE & $2.8 \pm 0.3^{\mathrm{A}}$ & $1.8-4.2$ & 2.8 & None \\
\hline 11 & ND-SE & $3.3 \pm 0.2^{\mathrm{A}}$ & $1.9-4.1$ & 3.6 & 3.6 \\
\hline \multirow[t]{2}{*}{26} & ND-W & $2.9 \pm 0.2^{\mathrm{A}}$ & $0.0-4.1$ & 3.3 & None \\
\hline & Average \& Range & $2.8 \pm 0.1$ & $0.0-4.2$ & 3.1 & 1.5 \\
\hline $\mathrm{N}$ & Region & $\begin{array}{c}\text { Mean OA } \pm \text { SE } \\
(\% \text { Oil })\end{array}$ & $\begin{array}{c}\text { Range for OA } \\
(\% \text { Oil })\end{array}$ & $\begin{array}{c}\text { Median for OA } \\
\text { (\% Oil) }\end{array}$ & $\begin{array}{l}\text { Mode for OA } \\
\text { (\% Oil) }\end{array}$ \\
\hline 9 & Canada & $18.9 \pm 0.9^{\mathrm{B}}$ & $15.0-24.2$ & 19.1 & None \\
\hline 8 & ND-NE & $20.4 \pm 0.5^{\mathrm{B}}$ & $18.4-22.7$ & 20.3 & 20.3 \\
\hline 11 & ND-SE & $23.8 \pm 1.8^{\mathrm{A}}$ & $16.9-31.5$ & 20.9 & None \\
\hline \multirow[t]{2}{*}{26} & ND-W & $19.4 \pm 0.4^{\mathrm{B}}$ & $13.4-22.8$ & 19.7 & None \\
\hline & Average \& Range & $20.4 \pm 0.5$ & $13.4-31.5$ & 19.6 & 19.6 \\
\hline $\mathrm{N}$ & Region & $\begin{array}{c}\text { Mean LA } \pm \text { SE } \\
(\% \text { Oil })\end{array}$ & $\begin{array}{l}\text { Range for LA } \\
\text { (\% Oil) }\end{array}$ & $\begin{array}{l}\text { Median for LA } \\
(\% \text { Oil })\end{array}$ & $\begin{array}{l}\text { Mode for LA } \\
\text { (\% Oil) }\end{array}$ \\
\hline 9 & Canada & $15.2 \pm 0.4^{\mathrm{B}}$ & $13.6-16.5$ & 15.6 & None \\
\hline 8 & ND-NE & $16.5 \pm 0.4^{\mathrm{A}}$ & $14.6-17.8$ & 16.8 & None \\
\hline 11 & ND-SE & $16.6 \pm 0.3^{\mathrm{A}}$ & $14.4-18.1$ & 16.7 & None \\
\hline \multirow[t]{2}{*}{26} & ND-W & $16.4 \pm 0.3^{\mathrm{BA}}$ & $12.5-20.1$ & 16.4 & None \\
\hline & Average \& Range & $16.2 \pm 0.2$ & $12.5-20.1$ & 16.4 & 16.4 \\
\hline & & Mean ALA \pm SE & Range for ALA & Median for ALA & Mode for ALA \\
\hline $\mathrm{N}$ & Region & (\% Oil) & (\% Oil) & (\% Oil) & (\% Oil) \\
\hline 9 & Canada & $58.8 \pm 0.8^{\mathrm{A}}$ & $53.7-61.9$ & 59.1 & 59.1 \\
\hline 8 & ND-NE & $54.2 \pm 0.6^{\mathrm{BC}}$ & $50.9-56.5$ & 54.2 & None \\
\hline 11 & ND-SE & $51.4 \pm 2.0^{\mathrm{C}}$ & $43.2-59.7$ & 55.3 & None \\
\hline \multirow{2}{*}{26} & ND-W & $56.3 \pm 0.7^{\mathrm{BA}}$ & $50.9-65.9$ & 56.5 & 56.9 \\
\hline & Average \& Range & $55.4 \pm 0.6$ & $43.2-65.9$ & 56.1 & 59.1 \\
\hline
\end{tabular}

Note: ND-NE indicates North Dakota (US) - North East region; ND-SE indicates North Dakota (US) - South East region; ND-W indicates North Dakota - West region; SE indicates Standard Error; SA indicates Stearic Acid; OA indicates Oleic Acid, LA indicates Linoleic Acid; ALA indicates Linolenic Acid; Different capitalized letters in superscript within the same column indicates mean values are significantly different at $\alpha=0.05$ 
The ALA composition in the oil appears to be high in both 2008 and 2009 compared to previous existing data (Table 1). The overall average ALA content among all samples from 2008 and 2009 (i.e. two-year average) was $55.4 \pm 0.6 \%$ (Table 5). Typical ALA values from flaxseed grown from the early part of the decade were 50-53\%. The higher values recently might be explained by improved production practices or simply the effect of growing region. In general, the ALA content of flaxseed from the Northern regions appears to be the highest. The flaxseed from western Canada in 2004 had ALA content as high as 61.9\% (DeClercq, 2005), and in year 2009, it was reported to be about 58\% (Barthet, 2010). Flaxseed samples obtained from Canada in the present study had similar values with the highest average ALA content of 58.8\%, followed by ND-W region $(56.3 \%$ ), and the lowest values were found in ND-SE region (51.4\%). This observation supports the basic observations that cooler climates cause plants to produce higher levels of unsaturated fatty acids. Also, the high ALA content could have a positive impact on overall nutritive value and general health benefits for humans ranging from reducing blood cholesterol to reducing platelet adhesivenesss (Loria, 1993; Cunnane \& Thompson, 1995; Guan et al., 1998; Oomah, 2001).

The growing season of 2009 was North Dakota's $36^{\text {th }}$ coolest summer and the $21^{\text {st }}$ driest (since 1895), thus the lower moisture contents of flaxseed grown in 2009 may be related to the drier harvest period (Akyuz \& Mullins, 2009). The growing season of 2008 was slightly warmer than 2009 in North Dakota, and ranked as the $46^{\text {th }}$ coldest and $46^{\text {th }}$ wettest (since 1895) (Akyuz \& Mullins, 2008). Rains during the harvest period may have contributed to the slightly higher moisture levels observed in the 2008 samples. Overall, the basis for the elevated oil and ALA contents in 2009 may be indicative of the cooled growing season and thus, differences between the two years in this study.

\section{Conclusion}

The pre-cleaned flaxseed had an average of $5.7 \pm 0.1,4.1 \pm 0.2,4.5 \pm 0.2,3.6 \pm 0.1$, and $3.0 \pm 0.1 \log$ colony forming units (CFU) $\mathrm{g}^{-1}$ of $\mathrm{APC}, \mathrm{CC}, \mathrm{EC}, \mathrm{YC}$ and $\mathrm{MC}$ respectively. For cleaned seed, the microbial count averages were $5.0 \pm 0.1,3.4 \pm 0.2,3.7 \pm 0.2,3.0 \pm 0.1$, and $2.3 \pm 0.1 \log \mathrm{CFU} \mathrm{g}{ }^{-1}$ of APC, CC, EC, YC and MC respectively. The cleaning of flaxseed was beneficial in reducing the microbial counts and should be considered an important step in maintaining high quality flaxseed. Only ND-W region had higher counts than other regions tested. For APC however, the counts were higher in flaxseed from Canada when compared to North Dakota. Although, the flaxseed samples obtained in 2008 and 2009 represent a typical year with regards to oil (average of $41.9 \pm 0.3 \%$ ) and moisture (average of $7.2 \pm 0.2 \%$ ) contents. However, the high ALA contents $(55.4 \pm 0.6 \%$ ) observed were unique for these two crop years. Although this survey evaluated a limited number of samples (54), the oil and fatty acid profiles indicate that the cooler growing seasons of 2008 and 2009 may have contributed to the higher ALA values. Overall, cool growing regions seem to have a positive effect on the overall ALA (chemical nutrients) content in the flaxseed. Also, cleaning of flaxseed can help in decreasing the overall microbial load on the seed.

\section{Acknowledgments}

The project was supported by the USDA Cooperative State Research, Education and Extension Service, special research grant number 2008-34328-19146 through the Midwest Advanced Food Manufacturing Alliance (MAFMA) program.

\section{References}

Akyuz, A., \& Mullins, B. A. (2008). 2008 Growing season weather summary for North Dakota. Retrieved from https://www.ndsu.edu/fileadmin/ndsco/ndsco/growing_season/2008.pdf

Akyuz, A., \& Mullins, B. A. (2009). 2009 Growing season weather summary for North Dakota. Retrieved from https://www.ndsu.edu/fileadmin/ndsco/ndsco/growing_season/2009.pdf

AOCS (American Oil Chemist Society). (1998). Method Ba3-38. In Official Methods of Analysis, Urbana, IL: American Oil Chemist Society.

Barthet, V. J. (2010). Quality of western Canadian flaxseed 2009. Canadian Grain Commission, 1-14.

Bean, L. D., \& Leeson, S. (2002). Fatty acid profiles of 23 samples of flaxseed collected from commercial feed mills in Ontario in 2001. The Journal of Applied Poultry Research, 11, 209-211. https://doi.org/10.1093/japr/11.2.209

Berry, E. M., \& Hirsch, J. (1986). Does dietary linolenic acid influence blood pressure? The American Journal of Clinical Nutrition, 44, 336-340.

Chen, Z. Y., Ratnayake, W. M. N., \& Cunnane, S. C. (1994). Oxidative stability of flaxseed lipids during baking. 
Journal of the American Oil Chemists' Society, 71, 629-632. https://doi.org/10.1007/BF02540591

Coskuner, Y., \& Karababa, E. (2007). Some physical properties of flaxseed (Linum usitatissimum L.). Journal of Food Engineering, 78(3), 1067-1073. https://doi.org/10.1016/j.jfoodeng.2005.12.017

Cunnane, S., \& Thompson, L. U (Eds.). (1995). Flaxseed in human nutrition. Champaign, IL: AOCS Press.

DeClercq, D. R. (2005). Quality of western Canadian flaxseed 2004. Canadian Grain Commission, 1-14.

Deible, K. E., \& Swanson, K. M. J. (2001). Cereal and cereal products. In F. P. Downes, \& K. Ito (Eds), Compendium of Methods for the Microbiological Examination of Foods (pp. 549-553). Washington, DC: American Public Health Association. https://doi.org/10.2105/9780875531755ch55

Djoussé, L., Pankow, J. S., Eckfeldt, J. H., Folsom, A. R., Hopkins, P. N., Province, M. A., Hong, Y., \& Ellison, R.C. (2001). Relation between dietary linolenic acid and coronary artery disease in the National Heart, Lung, and Blood Institute family heart study. The American Journal of Clinical Nutrition, 74, 612-619.

Doyle, M. P., \& Erickson, M. C. (2006). Closing the door on the fecal coliform assay. Microbe, 1, 162-163. https://doi.org/10.1128/microbe.1.162.1

GIPSA (Grain Inspection, Packers and Stockyards Administration, Federal Grain Inspection Service). (2004). General information. In Grain Inspection Handbook (pp. 1-42). Washington, DC: U.S. Department of Agriculture.

Graves, R. R., Rogers, R. F., Lyons, Jr. A. J., \& Hesseltine, C. W. (1967). Bacterial and actinomycete flora of Kansas-Nebraska and Pacific Northwest wheat and wheat flour. Cereal Chemistry, 44, 288-299.

Hettiarachchy, N., Hareland, G., Ostenson, A., \& Balder-Shank, G. (1990). Composition of eleven flaxseed varieties grown in North Dakota. Proceedings of 53rd Flax Institute of the United States, 36-40.

Hu, F. B., Stampfer, M. J., Manson, J. E., Rimm, E. B., Wolk, A., Colditz, G. A., Hennekens, C. H., \& Willett, W.C. (1999). Dietary intake of alpha-linolenic acid and risk of fatal ischemic heart disease among women. The American Journal of Clinical Nutrition, 69(5), 890-897.

ICMSF (International Commission on Microbiological Specifications for Foods). (1998). Cereal and cereal products. In Microorganisms in Foods 6: Microbial Ecology of Food commodities (pp. 313-355). New York, NY: Blackie Academic and Professional.

Lee, R. E., Manthey, F. A., \& Hall, C. A. (2003). Effects of boiling, refrigerating, and microwave heating on cooked quality and stability of lipids in macaroni containing ground flaxseed. Cereal Chemistry, 80(5), 570-574. https://doi.org/10.1094/CCHEM.2003.80.5.570

Manthey, F. A., Schorno, A. L., \& Hall, C.A. (2009). Effect of immature and off-colored seeds on the lipid quality of milled flaxseed. Journal of Food Lipids, 16, 407-420.

https://doi.org/10.1111/j.1745-4522.2009.01155.x

Manthey, F. A., Wolf-Hall, C. E., Yalla, S., Vijayakumar, C., \& Carlson, D. (2004). Microbial loads, mycotoxins, and quality of durum wheat from the 2001 harvest of the northern plains region of the United States. Journal of Food Protection, 67, 772-780.

Morris, D., \& Vaisey-Genser, M. (2003). Availablity and labeling of flaxseed food products and supplements. In L. U. Thompson, \& S. C. Cunnane (Eds.), Flaxseed in Human Nutrition (pp. 404-422). Champaign, IL: AOCS Press. https://doi.org/10.1201/9781439831915.ch22

Mueller, K., Eisner, P., Yoshie-Stark, Y., Nakada, R., \& Kirchhoff, E. 2010. Functional properties and chemical composition of fractionated brown and yellow linseed meal (Linum usitatissimum). Journal of Food Engineering, 98(4), 453-460. https://doi.org/10.1016/j.jfoodeng.2010.01.028

NASS (National Agricultural Statistics Service). (2009). 2007 Census of agriculture, United States, summary and state data. Retrieved from https://www.agcensus.usda.gov/Publications/2007/

Oomah, B. D. (2001). Flaxseed as a functional food source. Journal of the Science of Food and Agriculture, 81(9), 889-894. https://doi.org/10.1002/jsfa.898

Rubilar, M., Gutierrez, C., Verdugo, C., Shene, C. \& Sineiro, J. (2010). Flaxseed as a source of functional ingredients. Journal of Soil Science and Plant Nutrition, 10(3), 373-377. https://doi.org/10.4067/S0718-95162010000100010

Skyrme, D. S., Marks, B. P., Johnson, M. G., \& Siebenmorgen, T. J. (1998). Distribution of total aerobic and coliform bacterial counts among rice kernel components. Journal of Food Science, 63(1), 154-156. 
https://doi.org/10.1111/j.1365-2621.1998.tb15698.x

Sperber, W. H., \& The North American Miller's Association Microbiology Working Group. (2007). Role of microbiological guidelines in the production and commercial use of milled cereal grains: a practical approach for the 21st century. Journal of Food Protection, 70(4), 1041-1053.

\section{Copyrights}

Copyright for this article is retained by the author(s), with first publication rights granted to the journal.

This is an open-access article distributed under the terms and conditions of the Creative Commons Attribution license (http://creativecommons.org/licenses/by/4.0/). 